\title{
十條製紙の小集団活動
}

十條製紙秼生産部 大 野 茂 躬

\section{The small group activity in Jujo}

\section{Shigemi Ohno}

Jujo Paper Co., Ltd.

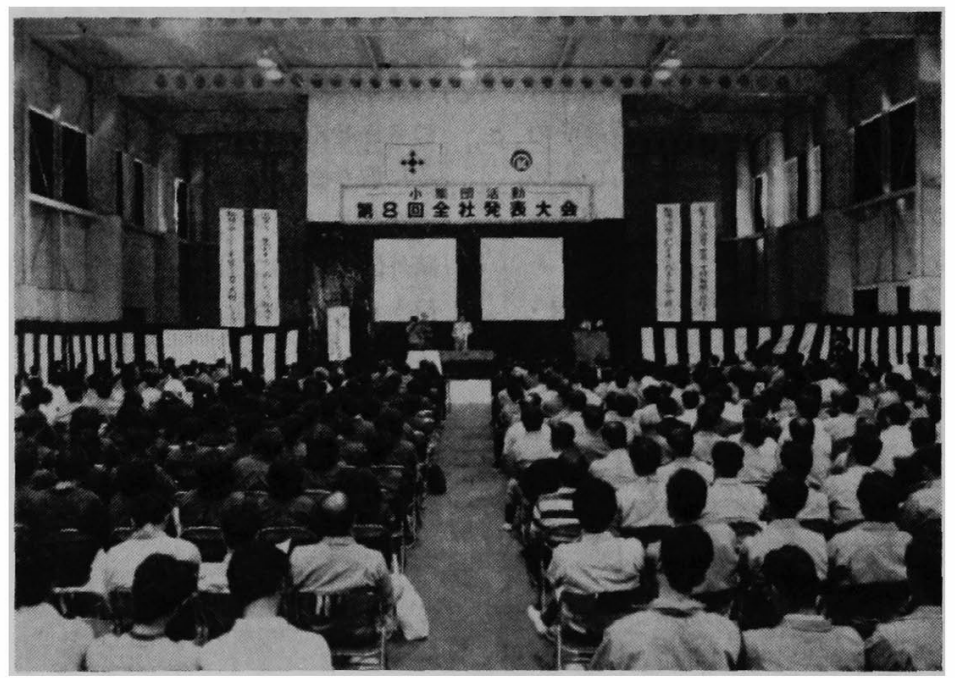

本年 5 月，石巻工場で開催された小集団活動全社発表大会

\section{1. 小集団活動導入の背景}

当社の小集団活動は昭和 52 年から 53 年の約 2 年間 にわたって経営トップ層を中心にして遵入準備がなさ れ, 昭和 53 年の中央労経協議会に怙いて会社から労 働組合に対して経営方針の大きな柱として提案された。 幸い労働組合の理解が得られ，昭和 54 年の 4 月から 10 月にかけて各工場がほぼー斉に小集団活動を開始 した。その後, 約 5 年遅れて昭和 59 年に本社部門で も小集団活動が実施に移された。

当社が小集団活動の導入を決意するに至った背景は 二つある。その一つは, 経営側のニーズとして「環境 変化に素早く対応できる組織作り」であり，もう一つ の背景は従業員サイドからの根強い「職場における人
間性尊重」要請に応兄るためであった。

最近は政治・社会・経済面でも，技術や顧客動向で も企業を取り巻く内外の環境変化は極めて激しい。こ れらの変化に対して企業が適切に対応できなければ， その命運にもかかわると言われている。環境変化に対 応できる組織体質とは，トップの方針で素早く組織全 体が動く組織体質であったり，あるいは，職場第一線 の従業員自らが旺盛に外部变化をとらえ，それに対応 するような職場体質などを指するのと思われる。この ような企業体質に改善するためには，企業の一部の人 々の活動たけでは不充分であって，職場の第一線従業 員も含めた全従業員が共通の問題意識をもって, 各自 の職場で安全や品質やコストダウンなどについて，自 主的に，そして，主体的に活䡃することなくしては望 
めないと考えられる。

一方, 現在の職場の第一線では製造工程のオートメ ーション化やロボット化, 事務・営業部門のコンピュ 一ターによる情報処理が急速なテンポで展開している。 このようにF A化やOA化が進んだ段階では，従業員 は仕事のなかに，そして仕事遂行プロセスのなかに主 体性や，生さがいを求めてもなかなか実現できない環 境になってきている。释営側がこのことに気つかず， あるいは無視して「企莱が指示した仕事を達成したら， その仕事の対価として貨金を支払いましょう。福利厚 生的恩恵を与えましょう」というような態度で接する ならば，従業員は職場における人間としての自分の存 在意義について慎疑的となり，勤労意欲の向上や賳場 の改善活動など望もべくるない状態になると思われる。

このような観点に立てば, 現在の企業組織が抱えて いろ大きな課題の一つは，「従紫員の持つ能力を，仕 事のなかに，いかにして発揮させるような新しい瞕場 を作るか」といらことに要約できるであろら。

同じ娥場の仲間同士が「自分たちの職場の具体的な 課題」を自主的に設定し，そして，その改善を小集団 活動の目的としてその改善活動を実施するとき，小集 団活動は次のように機能することが期待されている。

（1）小集団活動の場では，職制の枠を外してそれぞれ の役割を自主的に决めて活動するため，一人ひとり がその偒（小集団）になくてはならない貴重な戦 カとして尊重される。

（2）一人ひとりが，自分の目標を持ち，その達成に向 かって努力し，その目標達成によって大きな満足を 味わらことができる。

（3）職場の仲間と自由に話しあえるなど，良い雾用気 のなかで協力しあい，職場で自主的に設定した目標 の達成を目指して努力できる。

(4) 一人ひとりが積楅的に職場の改善活動に参画し, その害現に努力できる。

（5）職場の改善活動を通じて各自が自己啓発に努め， 各人の能力向上を図ることができる。 以上のような観点から, 小集団活動は経営側のニー ズにも，従業員側の要請にも応えるるのとして，当社 では経営の基本方針として採用することになったので ある。

\section{2. 小集団活動のねらい}

\section{第一の目的 従業只一人ひとりの能力向上}

当社が推進している小集団活動は単なる職場の改善 やZD，QCなどに片寄らず，これら全てを包括する 総合的な運動のなかで，従業員の能力向上を目指して
いる。従ってZ DやQ Cの特定の技法を身につけて， 特定範用の課題解决にねらいをしぱっているわけでは ない。職場のグループ活動を通じて従業員の自己㤵発 と相互啓発を促し，そのことによって人間として成長 を図り，企業組織のなかでの従業員本人の存在価值を 高めることを第一義とする運動である。

仕事は人を育てるものであるが，自主的に職場の周 辺の問題を見つけ，それを改善していく小集団活動に よって，従業員一人ひとりが成長していくことを期待 している。職場周辺の問題改善について, 自分たちで 計画段階から一貫してまとめあげた喜び，今まで成し 得なかったことを成し遂げた喜び，そのことによって みんなから認められた喜びを味わらとき，仕事のなか に真の喜びを見出すことができるようになる。そして 人間としての成長が期待されるのである。

\section{第二の目的 新しい猎場作り}

企業規模が大きくなり，組織化・機械化が進むと， そこに働く人々の行動は単なる機诚的行動の繰り返し になり，職場は労働提供の場だけになりがちである。 これでは職場に括いては人間としての喜びも働さがい もない。

一方，小集団活動においては，「改善テーマの設定」 から「現状分析」「改善案の立案」「実行」「効果確認」 「歯止め」などの一連の活動が，職場内のミーティン グをべースにしたメンバーの合意に基づいて展開され る。このミ一ティングでは全員が職制上の立場を雄れ て，言いたいことを本音で言らことができるので，そ の話合いによって自然に職場の人間関係がよくなり， 明るい職場にすることができる。

更に小集団活動の結果, 自分たちの職場の環境がよ くなったり，仕事がしやすくなったり，仕事が安全に できるよらになったり，コストが安くなったり，品質 が安定したといら体験をすると，「俺達がこの問題を 解決したんだ。そして, 工場のため, 会社のために, いい仕事をしたんだ。俺達がこの職場を支えているん だ。」といことを実感することができる。この達成 感と誇りが，職場に働きがい，生きがいを見出すこと につながることになる。

このようにして小集団活動の多くのグループが刺战 しあい，協力しあう関係になると，従業員にとって働 きがいのある新しい職場作りに大きく機能することに なる。

\section{第三の目的 企業業䋖の向上}

従業員が小集団活動に参加することによって，自分 達の職場の色々な問題を解決することになる。そして， その結果として職場のコストダウンや品質安定と安全 
管理の強化などに結びつき，企業業績の向上に寄与す ることになる。

\section{3. 小集団活動の活動状況とその成果}

\section{小集団活轻への荌四}

小集団活動への参加は自主参加を原則としている。 工場では管理職を除く一般従業員全員が小集団活動 のダループ編成対象者であり，管理職はその支援者と して関与することになっている。但し，一般従業員の なかの監督職（日勤係長）とスタッフの一部が支援業 務を担当していることもある。

本社では一般従業貝と，部艮・副部長などライン業 務に從事している管理職を除く管理職が小策団活動の メンバーとなっている。ライン部長は支援業務を担当 している。

以上のような小集団編成ルールに基つく小集団活動 組織率は 62 年 3 月 31 日現在で $98.3 \%$ に迲している。

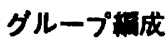

紙・バルプの製造現場は 24 時間連続操業である。 従って，操業部門では 4 組 3 交替制で係が編成されて いるので，小集団活動のグルーブ編成も交替保長単位 で編成することを原則としている。しかし，紙の仕上 検査部門のように常冝職場で大勢の作業員がいる職場 では，1ダルーブ5〜7 人で編成するよらにしている。 一方，事務部門のよ5に 1 人 1 業種のような職場では 総務課，経理課，勤労課など合同で 1 グルーブを編成 している例もある。

以上の上らなグルーブ編成で玩在のグループ数は 670 グルーブ（工場：588 グルーブ, 本社 : 82 グルー ブ)である。

ミーティンタ

ミーティングは小集団活動の基本といら理解の仕方 で：ミーティングは時間外で行らことを原則として， グループ月当り 2 回以上, 1 回のミーティングは約 2 時間程度を目標詣導してきている。しかし，小集団 活動を開始してから約 3 年間は全社平均で 1 回以下／ クループ・月であった。その後，「小雀団活和をなぜ やるのか」などの理解が深まるにつれて徐々に增加し， 昭和 59 年以降は 2 回/グルーブ・月の割合のミーテ イングが定着し，61 年度は 2.5 回/グループ・月の実 䋶であった。例外ではあるが，工場では年間 101 回 （月平均 8.4 回）ものミーティングをもつような熱心 なグルーブもでてきている。

\section{テーマの内容と目粠遠成件数}

職場の小策団活動は安全・品質・コストなど，いず れの目槚であってもその成否の大半はテーマの選び方
で決るといってよい。明確で成果が確かめられる目標 を決めておかないと活動に達成感が得られないし，的 確な進め方を期待することができない。当社ではテー マ設定にあたっては次のようなことに気をつけて指導 している。

（1）自分たちの職場で，今，痛切に困っている問題を 取り上げること。

(2) できるだけ具体的な問題を取り上げること。

(3) グループで解決の可能性のある問題を選ぶこと。

(4) 3〜4ケ月で達成できる問題を対象にすること。 具体的に完結した活動テーマを例示すると次の通り である。

安全関係のテーマ例

（1）紙仕上検查場所に批けるリフト・トラックと人と の接触防止対策

石巻工場・仕上検査課「パルック\&ストロベリー」

（2） 2P湿紙サンブリング方法の改善と安全作業基準 書の作成

石巻工場・第 3 抄造課「希望」

環境保全関係のテーマ例

（1）慣性集痤機取付による製紙污沱焼却キルン排出ば いじん湌度の低減

八代工場・環境管理室「グルーブ・スュール」

（2） 廃水処理経費の節減

勿来工場・大機分工場「月下美人」 品質管理関保のテーマ例

（1）スリッター紙粉の紙製品への混入防止対策 勿来工場・仕上検查課「新巻取之助」

（2）DIP白色度のバラッキ縮小と薬品添加量の見直し 伏木工場・原質課「歯車」 コストダウン関保テーマ例

(1) RGP 二次レファイナーモーター冷却ファンの省 電力

伏木工場・動力課「リペフーズ」

RGP のレフォイナーを駆動するモーターは，運転 により温度が上昇するため，冷却フォッで泠たい外気 をモーターに送り込灭冷却している。この命却フォン の年間の運転状況をチェックしてみたところ，外気温 が下がっても運転させていた。そこで，この邻却フ ンの節電ができないかを活動のテーマとした。

二次レファイナーKは，A系列の $5.5 \mathrm{~kW}$ とB系列 の $11 \mathrm{~kW}$ の 2 台の玲却ファンがあり, 年中運転して いた。そこで長期にわたる調査を基に，その節電につ いて検討した結果,

i） A系レファイナーは，単独の冷却フォンを持って いるので温度の高い反調節側のモーター温度を表示さ 


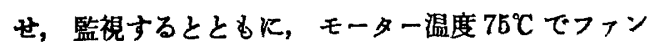

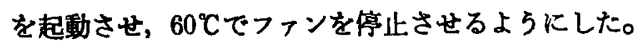
更に, 外気温が $20^{\circ} \mathrm{C}$ 以下になる 10 月から 4 月の 7 力 月は，冷却フォンを停止してもモーター温度が $75^{\circ} \mathrm{C}$ 以上に上䄯しないことがわかったので，この間は冷却 フォンモーターを停止することにした。

ii）B系では，モーターの温度が高いのでこれにセン サーを取付け，インバーターにより邻却フォンの回転 数制御により風量をコントロールし, 温度を $75^{\circ} \mathrm{C}$ 以 下にするようにした。

その結果，年間 110 万円の電力費を節約することが できた。

（2）黑液噴射ノズル改造によるボイラー重油消費量の 節減

釧路工場・汽機課「回収係Cチーム」

作業改善テーマ例

（1）目立機の改造によるグラインダー目立作業の要員 合理化

釧路工昜・第一原質課「オールドスターズ」 グラインダーストーンの目立作業を 2 人でやってい たが，要員合理化でグラインダー担当者が一人になっ たため，一人で目立作業ができるような装置の開発を テーマとした。

何回か失敗した後, 油王装固の切り替えレバーをり ンク機桡とし，足で操作できるようにした。 この改善により

i ）一人で目立作業ができるようになった

ii）一人で目立車の走行と切り込みをするため，目立 の仕上りが従来より良くなった

（特許申請中）

（2）抄轿譏小径ロール取替光治具の考案で，小径ロー ル取替時間の短樎

伏木工場・設計工作䛠「ニュ一立山」

抄紙譏の小径ロール（カンハスロール，フェルトロ ール，ワイヤーロールなど）の取替え作業は，先ずマ シンの表复フレームに鉄パイプを 2 本通し，次に導板 を渡し，その後鉄パイプでカンバスなどを釣上げ，口 一ルを 2 個の台車に乗せ，導板に沿わせて引き出して いた。この作莱は非常な労力と時間を要し，かつ危険 な作業であったため，この作業改善のための治具の考 案をテーマとした。

考案した治具の棈造は直径 $300 \mathrm{~mm}$, 長さ $4,600 \mathrm{~mm}$, の鋼管を長さ方向へ $100 \mathrm{~mm}$ の幅で切り取り，その両 側に 5 個ずつ計 10 個のべャリングを取付けてある。

ロール替えの手順は，ロールをワイヤーで釣り，治 具の切り取ってある溝部分を上にしてロールの面上を
ベャリングで受けて押し込む。そして治具を $180^{\circ}$ 回 転させて釣り，ロールはベヤリングで受け，治具の中 を落下の危険なく引き出す。

この治具の開発により，作業者は危険な作業から開 放され，口一ル替え時間も 4 時間から 1.5 時間に短縮 でき，作業員も6人から 4 人に減員することができた。 (特許申請中)

\section{研究開発関係テーマ例}

(1) CCP 品質試験の L A 化

中央研究所・特殊紙研究室「ヴィイキンズ」

（2）恒温室内の雑菌污染対策 中央研究所・化学品研究室「フルハウス」

本社の業務改善テーマ例

(1) 手形枚数消減と印紙税節減

本社・財䅂部・会計グループ「グループ FOREX」

(2) 商品マニュフルの作成

本社・資材部・主要品グループ「ハイイヤース」

注：「」内はグルーブのニックネーム

以上のようなテーマを 61 年度全社合計で 1,350 件, グルーブ平均で年間 2.2 件，検討し完結させている。 なお，最近 1 年間の完結テーマの件数と内容は表 1 の 通りである。

表 161 年度の完結テーマ件数と内容

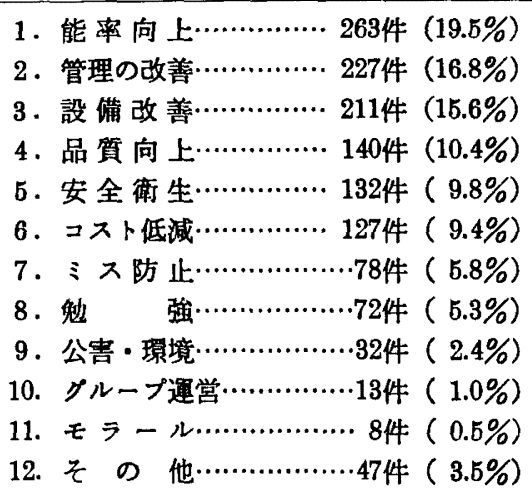

\section{成果甡表}

完結した成果について仲間に紹介し，上司の評価を 受けるため一つの活動テーマが完結すると，すべての クループが必ず課の発表会で発表することになってい る。その後, 部の発表会があって工場発表会や全社発 表大会の代表グループが選抜される。課と部の発表会 は完結テーマが集まり次第開催している。工場発表会 はほとんどの工場と本社が年 2 回（石巻工場は 4 回） 開催している。全社発表大会は年 1 回, 工場所在地持 ち回りで每年開催し，本年で 8 回を数えた。全社発表 


大 野 茂躬

大会には副社長以下経営のトップが出席し，成果発表 に対する講評と，ねざらいと激励の言葉をかけられる。 発表会の開催については，ともすれば発表会のため の小集団活動になるといら恐れもあるが，小集団活動 の活性化持続のためには必要な行事として毎年実行し ている。

\section{提案件数}

小集団活動の活性度を測定する項目の一つとして提 案件数がある。小集団活動実施前の件数は年間 500 件 以下であったが，小集団活動開始後 3 年を経過した 57 年から急速に增加しはじめ，61年には5,138 件に達 している。これを 1 グルーブ当りにすると 9 件となる。 この数字だけを見れば当社の提案件数は少ないように 見兄る。しかし，当社の提案の仕方は他社と若干異な り，あるテーマについてグループで検討し奻果があれ ばそれを確認したらえでグルーブ提案をする，といら よらな形を自然にとっている。従って，一つのグルー プ提案にはいくつもの提案が織り込まれていることを 付記しておく。

\section{小集団活刺の成果}

小集団活動による成果としてコストダウンのように 金銭的に評価できるものと，モラールアップのように 金銭的に評価できないものがある。

金銭的に評価できる経済的効果としては，55 年以 降每年, 省エネルギーや薬品の節減に代表される比例 費的な節減が年間 5 億円以上に達している。

一方，当社の小集団活動の本来的なねらいである職 場と従業員の活性化については，60 年 7 月，全管理 職を対象にアンケート調查を行ったところ，次の上ら な結論を得た。即ち大部分の管理職が表 2のよらな理 由を挙げて，職第の活性化のために小集団活動はある 程度の成果を収めていると評価している。

表 2 職場活性化に果した小集団活動成果

(1). 仕事に取り組む意識や意欲の向上 $\cdots \cdots . .21 .5 \%$

(2). 職場の活性化………………………...17.9\%

(8). 当該管理業務の向上………………....15.9\%

(4). 場内のコミュニケーションの円滑化 $\cdots 13.8 \%$

(5). ボトムアップの土䱋ができる………...10.7\%

(6. 職場のモラールアップ........................10.1\%

\section{4. 管理・監督者と小集団活動}

大部分の管理・監督者はそれぞれ部下をもち，通常， 部下を通して職務を遂行している。その部下のすへて か，いつも安全に作業し操業を安定させて品質基準を 維持し，コスト・ダウンを図ってくれれば問題はない
が，実際はなかなかそらはいかないのが普通である。 特に従来の指示・命令のみによる仕事の進め方だけで は，充分な業務の遂行は難しく，時には命令管理の強 化が部下のやる気を䯅失させてしまらことも拯々経験 することである。

一方，管理・監督者は部下の業務内容やその仕事の やり方のすべてを知っているわけではなく，むしろ気 がつかない，手が回らない，さらに命令ではでさない 上うな仕事が現場には数多くある。このような命令管 理の不充分さと，職場の第一線で働く部下の職場の問 題に対する無関心さが複合して，トラブルやクレーム が絶党ないといったケースが意外に多くあるものであ る。

従来の命令管理を主体とした仕事のやり方に，職場 第一線従業員による自主的な管理活動を補完した新し い仕事のやり方（小集団活動）は，職場第一線の從業 員が自主的に自分たちの職場の問題の改善活動を展開 し，業續向上に寄与してくれることを狙っている。従 って，小集団活動は率直にいって管理・監督者にとっ ては極めて有効な仕事のやり方と言えよ5。一方, 従 業員にとっては小集団活動をすることによって個人の 能力の向上につながり, 明るい職場つくりができ，自 分の生活の糃を得る場である企業の業績を向上させる ことができるわけで，自分の職場に働きがいと，生き がいを見出すことができることになる。

この小集団活動の中心になるのは，いらまでるなく 職場の第一線の従業員だが，これらの活動を積極的に 推進するのは実はラインの管理・監督者の役割である。 小集団活動はスポーツや趣味のよらな面白さはないが， スポーツや趣味に熱中するような從業員の能動的な行 動を必要とする。従って，この活動は管理・監督者が どのように従業員の能動性を引出すかが大切なポイン トである。自主管理活動たからといって管理・監督者 が消極的であったり，関心の示し方が薄い場合は小集 団活動は決してらまく展開しない。小集団活動を効果 的，継続的に進めていくためには管理・監督者が自分 の担当する職場の職場風土に見合った積極的な支援活 動を必要とするのである。

管理・監督者が小集団活動を支援する場合の一番大 切なととは，管理・監督者とグルーブ・メンバーの間 の信頼関係を維持することである。管理・監督者の命 令で信頼関係が生まれてくるものではなく，一緒に同 し立場に立って小集団活動を考光行動することが大切 である。部下が小集団活動を通して意欲的に仕事に取 り組めるようにしたとき，その職場の業續が大きく向 上するといらことは数多くの実綨が証明している。 


\section{5. 小集団活動の推進組織}

小集団活動を長期にわたって運営していくためには 活動全体を支える組織が必要である。当社では全社の 小集団活動を生産部が事務局として統括している。小 集団活動に関する基本方針，年度計画扣よび予算の審 議，立案は社長直轄の教育委員会で行う。

工場および本社の小集団活動を推進する組織として 各事業所に推進委員会がある。その代表例を上げると 図1の通りである。この推進委員会は事業所の小集団 活動の円滑な推進をはかるために次のような業務を行 5。

（1）事業所の小集団活動推進関する提言

（2）事業所の小集団活動の有成，推進の援助のための 諸企画諸制度の立案および実施

（3）事業所の小集団活動発表会の企画拉よび実施

（4）事業所小集団活動実積の把握，情報収集，資料の 整備

（5）他社との交流

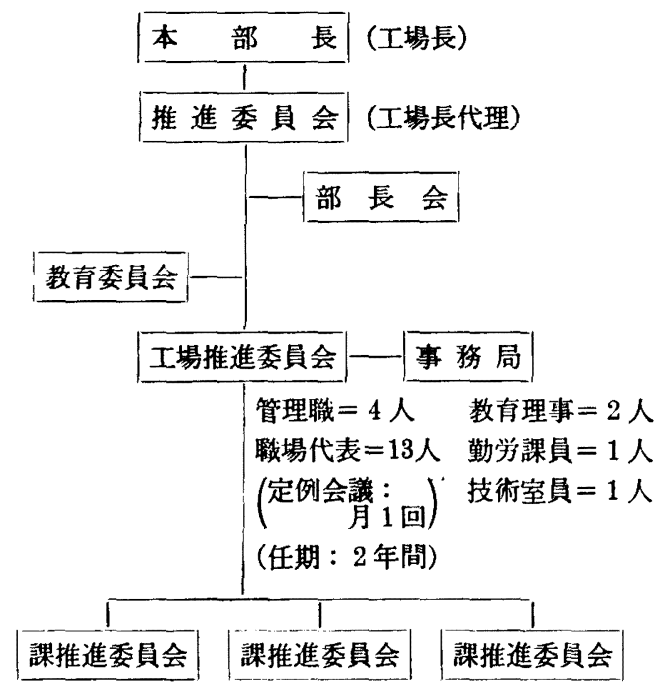

図1 釧路工場の小集団活動推進組織

\section{6. 小集団活動の教育}

\section{小集団活動教育の経逼}

当社では小集団活動を活性化させるための支援活動 は，教育に始まり教育に終ると考兄，小集団活動関俰 の教育にはかなりの力を入れているつもりである。

昭和 54 年から 57 年までの小集団活動䢙入期は，外 部のコンサルタントに依頼してリータ゚ーおよび支援者
の教育を行った。しかし，その後，本社に小集団活動 専任の担当者を配置したこともあって，最近では尃ら 社内講師に上る研修が行われている。小集団活動の教 育を社内で実施するメリットは次の通りである。

（1）自社の問題解決事例を豊富に取り入れた教育がて きる

（2）スケジュール，カリキュラムを自社の都合に合わ せて自由に設計できる

（3）教育コストを大幅临節減でさる

当社の社内に批りる小集団活動関係教育には，本社 主催の(1)小集団活動支援のための管理職研修会，(2)小 集団活動支援のための監督職研修会，(3)小集団活動り 一ダー研修会，(4)技能交流会，(5)手法インストラクタ 一研修会などがある。工場主催の教育では(1)リーダー 研修会，(2)係長研修会，(3)支援者研修会，(4)グループ 合宿研修会（担当課長を交えた倸全員のフォミリー・ トレーニンクー後述一)などを実施している。これら 教育に要する費用は昭和 61 年度の予算で約 1 億 2 千 万円であった。

\section{小集団活形教育の進め方}

小集団活動教育恃座学形式か，体験学習形式かは議 論の分かれるところたが，当社では小集団活動の成炛 度合に応じて使いわけしている。すなわら，小集団活 動の導入当時とか, 小集団活動末熟グループに対して は，「なぜ，われわれは小集団话動をやらなければな らないのか」「小集団活動と職制活動との関係」「リー ダーの役割」など観念的な問題で悩むりーダーや支援 者が多いので，この場合は座学形式でじっくり教克， その後にグルーブ討議で更に理解を深めさせるように している。

一方，ある程度小集団活動の体験を櫴んでざたら， リーダーとして効率的に活動するためのノウハウ，例 えば,グルーブ討議の仕方，メンバーのやる気の起さ せ方, 問題の見つけ方とその原因の解明の仕方, 改善 案の作り方，QC 7 ッ道具, グループ発想法などにつ いて体験学習的に研糸している。

いずれにせよ，小集団活動は実践活動なので，小集 団活動の理論や手法などの物知りではあるが実践行動 カがないような人を作る教育であってはならないと考 えている。

\section{今，最もカを入れているグループ合宿研僆}

当社では小集団活動が始まってから 3 年間䚾どは， 相当数の従業員を外部研修に出して教育したつもりた が，どらもその教育が職場に定着しなかった。その理 由を探ってみたところ，次のよらなことが分かった。 すなわち，(1)外部研修を受けた従業員は受講直後は色 
々な刺㦸を受けて，然えて職場に庆り，そして行動に 移す。ところが，職場の大部分の従業員はそのような 動機づけがされていないので，それが職場から浮き上 がった言動として受けとめられる。(2)グルーブのなか の特定の人だけが活動しても，本当の小集団活勘にな らない。(3)メンバー全員に共通の意識をもたせなけれ ば職場のエネルギーが結集されない。

これらの反省から，1 係全員が同時偟同じ教育を受 け，俰員全員のやる気を触発するような社内研修を手 作りで開発した。その研修要領は次の通りである。

（1）係長から一般係員まで，係員全員の 1 泊・2 日の 合宿研修。1シフトの色なな係が同時に参加

（2）研修会場は最奇の国民宿含か社内施設

（3）座学より体験学習に重点を沮く

(4) 䊔師は社内の部課長クラスの社内绕師および社内 手法インストラクター

（5）研修のメーソ・テーマ=「自分達の職場で，今， 一番困っている問題はなにか。そして，その解决策 はなにか」

（6）担当課長も出席。職場の生の声を䦥き，道切なつ ドバイスをする。更に職場からの要請事項について 「やる，やらない」の意志表示をはっきりする。そ して約束したことは確実に実行する

（7）各グループはグループ討議の結果を全研修生と工 場幹部に対して発表する

（8）グループ討議の結果を工場幹部はしっかり聞いて 「今後の活動に期待している」と湤励してやる このグルーブ合宿研览の教育効果はこれまでの実緢 を点検すると次の通りである。

（1）クループ・メンバー全員が共通の問題意識をむつ ことがでさる。更に，触発され，やる気を出す

（2）職場の第一線の從業員が日頃接触の少ない工場長 や部・課長など工場幹部と直接話合いができ，工垉 幹部の工場運営方針を知ることがでさる。一方，工 場幹部は職場の生の声を聞くことができる

(3) 職場周辺の問題の見つけ方と原因の解明の仕方, 統計手法の使い方, 改善案の作り方, 発表の仕方な どについ，グルーブ全員で同じレベルで不公平な く習得でる

（4）職場内の心のこもった意志踈通ができる

\section{7. 今後の課題}

\section{管理職の業楼目柾とグループの自兴目标の整合}

当社では管理職を対象とする「業績目標管理制度」 があって，铂期，当輆工場畏もしくは部長の方針に基 づき，コスト・品筫・安全・職場の活性化などについ
て具体的な目嫩を設定し，それを央現することが要求 される。それを達成するためにある管理職は職制を通 じて命令で実現しようとする場合るあるし，ある管理 職はスタッフを使ってその実現を図る場合もある。

小集団活動が始まってからは，管理職に対して「業 績目標の内容によっては，どんどん小集団活動でやっ てもらいなさい。特に，作業標準書のようなものは， 課長やスタッフが机上で書くよりも，小集団活動の場 で作ってもらった方がより現場で守られる実践的な基 準畫ができる」と指導している。そして，機会あるご とに自分の業績目標を小集団活動グループに流す努力 をすることを求めてきた。

ところが前述の管理職を対象にしたアンケート調査 のなかで，「活動テーマ・目標について規制や方向つ けをせずに自由に選ばせているので職制の業務目標と 無関係である」と約 20\%の管理職が回答している。 すなわち，まだ職場の業績目標とグループの自覚目 標を整合させることが管理職の重要な業務の一部であ る」ことの琵識に欠ける管理職がいるわけで，今後， 一般従業員の小集団活動教育と並行して，小集団活動 支援者としての管理職研修にも注力する必要があると 考えている。併せて小集団活動グループに対して「よ いテーマ」を提供でさる最短距離にいる職場の上司が その業務目摽と小集団活動グループ目摽をよりスムー スに整合させる方法について研究を進める必要がある と考えている。

\section{小柴団活功の成果の見返り}

ある事業所で一般従業員を対象にして小集団活動に 関するフンヶート調査を実施したところ，小集団活動 の見返りが少ないという意見が相当数あった。これら 従業員が指摘するこの見返りのなかには，当然，金銭 的な報判が入っていることは明らかである。

しかし，改善成果に対して金銭的に報いる方法も当 然あるが，そればかりでこの問題は解決しないように 思われる。『支援者が絶えず自分達のそばで活動を見 守ってくれている。そして，活動の成果に対して十分 な理解と評価をフィードハッックしてくれる。すなわち 達成の喜びを支援者と共に分かちあえることが一番嬉 しい』という現場第一線の声がある。われわれとして は，これが最も大きな見返りであり，次の活動の原動 力となるのではないかと考えている。

なお，活動のレペルアッブを図ることが成果に対す る喜びをより大きくするものと思われるので，社内外 の研修や，他社・他工場の発表会参加などの機会をよ り增やす方針である。 